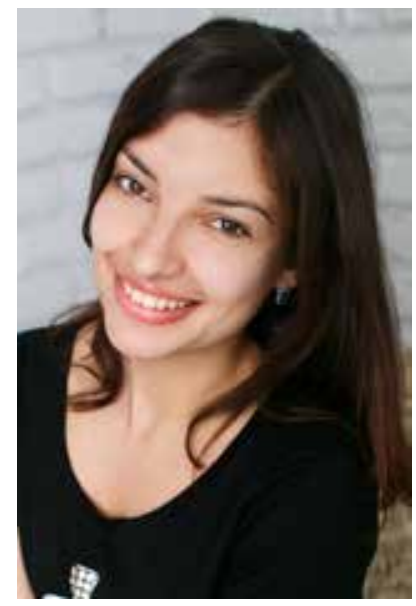

\author{
Натемла Роскошна, \\ аспірантка кафредри \\ кримінально-правових Аисциплін \\ юрихичного фракультету \\ Харківського національного університету \\ імені В. Н. Каразіна
}

https://doi.org/10.32782/2020-38-12

УДК 343.1

\title{
Медіація у рамках угоди про примирення між потерпілим та підозрюваним чи обвинуваченим
}

Медіація як спосіб альтернативного вирішення спорів набула поширення майже по всьому світу, про що свідчить наявність відповідних законів у законодавстві багатьох держав. Медіація як прогресивний спосіб вирішення спорів робить акцент не на фактах, що вже в минулому, і не на тому, хто правий, а хто ні, медіація працює 3 тією ситуацією, яка є нині актуальною, і шукає рішення з тим, щоб змінити іiї на краще. У кримінальному процесі медіація є однією 3 форм відновного правосуддя, яка містить у собі прагнення відновити становище, яке існувало до скоєння злочину, якщо це можливо, і зробити це у такий спосіб, який може допомогти обом сторонам цього злочину - i потерпілому, i злочинцю. Зазвичай медіацію у кримінальному процесі називають «програмою примирення потерпілих і правопорушників».

Програми примирення потерпілих і правопорушників виникли наприкінці $70-x$ років у США та на початку 80-х у Свропі. Першою з європейських країн цю програму ініціювала Великобританія. Натепер програми примирення не лише успішно функціонують у Норвегії, Фінляндії, Австрії, Німеччині та Франції, але й закріплені на рівні національних законодавств. В інших країнах Європи було зроблено перші кроки у цьому напрямі - пілотні проєкти у Данії, Швеції, Нідерландах, Ірландії, Іспанії та Італії. Протягом останніх років активізувався рух за впровадження програм примирення у Східній Європі [1, с. 42].

Зважаючи на те, що натепер судова система України переживає «кризу завантаженості», суди не справляються з обсягом роботи, який на них припадає, Україна вже не стоїть перед вибором: запроваджувати процедуру медіації чи ні. Це реальна необхідність, якої потребує суспільство і яка повинна набути законодавчого оформлення. Світова практика вже довела ефективність медіації як нового, прогресивного способу альтернативного 
вирішення конфліктів чи спорів. Тому на поточний момент залишаються лише технічні питання запровадження такої процедури. Зважаючи на те, що майже всі сфери застосування медіації не потребують особливого законодавчого врегулювання, окрім кримінального процесу, саме ця сфера застосування медіації викликає найбільше питань.

До аргументів необхідності запровадження медіації у кримінальному процесі можна навести такі акти органів Свропейського співтовариства: Рекомендацію Комітету Міністрів Ради Європи № R (99)19 від 19 вересня 1999 р. «Про посередництво в кримінальних справах», Резолюцію Економічної і Соціальної Ради ООН 2002/12 від 24 липня 2002 р. «Основні принципи застосування програм реституційного правосуддя в питаннях кримінального правосуддя», Керівництво Європейської Комісії 3 ефективності правосуддя від 7 грудня 2007 р. $з$ поліпшення реалізації раніше прийнятої Рекомендації «Про медіацію у кримінальних справах», Декларацію ООН 1999 р. «Основоположні принципи використання відновного правосуддя», в яких містяться пропозиції щодо впровадження в національні процесуальні системи медіації у кримінальних справах. Медіація, як сказано в Рекомендації Кабінету Міністрів Ради Свропи № R (99)19 від 15 вересня 1999 р., - це процес, у якому жертва і правопорушник мають можливість добровільно брати участь у вирішенні породжених злочином проблем, використовуючи допомогу неупередженої третьої сторони, або посередника [3; 5; 6].

Як уже зазначалося, натепер в Україні досі триває процес запровадження нового способу альтернативного вирішення спорів, який уже встиг набути поширення по всьому світу. Українські законодавці вже робили декілька спроб прийняти закон, який би регулював медіацію, але всі законопроєкти були відхилені. Тому 22 квітня 2020 Кабінетом Міністрів України був схвалений новий проєкт Закону «Про медіацію» № 3504 [5].

У законопроєкті медіація визначається як добровільна, позасудова, конфіденційна, структурована процедура, під час якої сторони за допомогою медіатора (медіаторів) намагаються врегулювати конфлікт (спір) шляхом переговорів [5].

Із цього можна зробити висновок, що законодавці вибирають позасудову медіацію, а не наприклад присудову. При цьому у п. 1 ст. 13 проєкту Закону також зазначається, що державні органи та органи місцевого самоврядування можуть вести та оприлюднювати реєстри медіаторів, яких вони залучають або послугами яких користуються [5].

Цей проєкт Закону передбачає можливість застосування медіації також і до кримінальних проваджень. Насамперед ч. 1 ст. 2 законопроєкту України «Про медіацію» зазначає, що медіація може застосовуватися у будьяких конфліктах (спорах), які виникають у тому числі у кримінальних провадженнях під час укладання угод про примирення між потерпілим та підозрюваним, обвинуваченим [5].

Тобто у Кримінальний процесуальний кодекс України не будуть вноситись додаткові зміни, окрім, як зазначено у прикінцевих та перехідних положеннях законопроєкту, таких: «частину другу статті 65 доповнити пунктом $8^{1}$ такого змісту: $\left.\ll 8^{1}\right)$ медіатори - про відомості, що стали їм відомі та/або одержані ними під час проведення медіації»; друге речення абзацу першого частини першої статті 469 після слів «за допомогою» доповнити словами «медіатора (медіаторів)» [5].

Така логіка законодавців є цілком зрозумілою, по-перше, через те, що сама процедура медіації за своєю 
філософією $є$ процедурою примирливою, яка має на меті досягнення домовленостей і подолання непорозумінь за допомогою третього нейтрального посередника. По-друге, VI розділ Кримінального процесуального кодексу України, який уже містить у собі статті, які передбачають процесуальний порядок досягнення угоди про примирення між потерпілим та підозрюваним чи обвинуваченим повністю передбачає всі необхідні елементи для реалізації процедури медіації у кримінальному процесі [6].

Тобто 3 технічної точки зору функціонування медіації у рамках кримінального провадження зрозуміле. Також слід зазначити, що весь понятійний апарат, що стосується процесу медіації, статус медіатора, а також порядок проведення процедури медіації зазначаються у проєкті Закону «Про медіацію».

У ч. 3 ст. 4 проєкту Закону «Про медіацію» зазначено, що участь сторони в медіації не може вважатися визнанням такою стороною вини, позовних вимог або відмовою від цих вимог, що теж є принципово важливим моментом для кримінального процесу [5]. Таким чином, Закон дає можливість обвинуваченому чи підозрюваному брати участь у медіації, не остерігаючись наслідків для себе, що робить цю процедуру для них більш привабливою.

Разом із тим у ч. 1 ст. 5 законопроєкту України «Про медіацію» зазначено, що принцип конфіденційності не застосовується у разі, коли розкриття інформації необхідне для запобігання заподіянню шкоди фізичному чи психічному здоров'ю особи або вчиненню кримінального правопорушення [5].

Тобто, якщо в процесі медіації стало відомо про можливість вчинення якоюсь особою правопорушення або шкоди психічному чи фізичному здоров'ю, медіатор, як і інші сторони, має законне право розповісти про це, і до них не буде застосовуватись відповідальність за поширення конфіденційної інформації.

Проаналізувавши вищезазначений законопроєкт, можна дійти висновку, що якихось особливих норм, що регулювали б медіацію у кримінальному процесі, в ньому майже не міститься.

На мою думку, цього не досить 3 огляду на те, що кримінальний процес має свою специфіку, тому навіть медіація у кримінальному процесі повинна трохи відрізнятись.

Наприклад, вимоги до медіатора у кримінальному процесі, на мою думку, мають відрізнятись. Медіатор, що бажає працювати у цій сфері, додатково до тих вимог, що зазначені у законопроєкті, повинен пройти спеціальне навчання саме для медіації у кримінальному процесі. Він має розуміти, як працювати із кризовим психологічним станом жертви злочину, як готувати іiі до спільної сесії медіації зі злочинцем, також медіатор повинен вміти розмовляти зі злочинцем, додержуючись своєї «нейтральної позиції». На мій погляд, було б доречно, щоб на медіації між жертвою злочину та обвинуваченим чи підозрюваним працювали одразу два медіатори, щоб хоча би в одного з них була психологічна освіта. Також я вважаю, що перед тим, як працювати медіатором у цій сфері, людина, після проходження відповідних курсів, повинна поспостерігати декілька реальних сесій медіації між потерпілим та обвинуваченим чи підозрюваним за участю професійних медіаторів, підписуючи всі угоди про конфіденційність.

Також незрозумілим залишається питання оплати праці медіатора у разі, якщо хтось зі сторін спору нездатний оплатити послуги медіації через скрутний стан. На мою думку, держава повинна була би створити реєстри медіаторів, які готові безоплатно надавити послуги медіації у кримінальному процесі, або наприклад, мати 
штатних медіаторів у суді, які у разі потреби могли б провести медіацію. Але законодавець вибрав позасудову модель медіації, що з фінансової сторони є більш вигідним варіантом тому, що для присудової медіації потрібно витрачати кошти державного бюджету, щоб оплатити роботу медіатора, але, на мою думку, держава повинна забезпечувати доступ до медіації як до одного 3 видів відновного правосуддя. Цей висновок був зумовлений за аналогією 3 «правом на безоплатну адвокатську допомогу».

Разом із тим у ст. 12 законопроєкту «Про медіацію» закріплено такий обов'язок медіатора, як не рідше одного разу на рік на безоплатній основі надавати послуги з проведення медіації, у якій однією зі сторін є особа, яка перебуває під юрисдикцією України, якщо iii середньомісячний дохід не перевищує двох розмірів прожиткового мінімуму, розрахованого та затвердженого відповідно до закону для осіб, які належать до основних соціальних і демографічних груп населення, або особа 3 інвалідністю, яка отримує пенсію або допомогу, що призначається замість пенсії, у розмірі, що не перевищує двох прожиткових мінімумів для непрацездатних осіб, у разі звернення таких осіб до медіатора [5].

3 одного боку, цю норму можна віднести як спробу законодавця створити доступ до цієї послуги, але 3 іншого - незрозуміло щодо наприклад спеціалізації медіатора. За логікою законодавця, якщо людина, яка не розуміє спеціалізацію медіатора, звернулась за допомогою у разі конфлікту у кримінально-правовій площині, a медіатор, наприклад, займається сімейною медіацією, він не має права їй відмовити. Із цього можна зробити висновок, що медіаторам потрібно визначитись зі спеціалізаціями, а цю норму закону доповнити: «якщо конфлікт чи спір цієї особи підпадає під спеціалізацію медіатора».
Також незрозуміло, яку відповідальність буде нести медіатор у зв'язку із невиконанням цього обов'язку. Розуміючи той факт, що медіація конфіденційна і відомості про факт ії̈ проведення теж конфіденційні, можна припустити, що медіатор може розмістити неправдиві відомості про проведення такого роду медіації, і це не можна буде перевірити законним шляхом.

Додаючи до вищенаведеного, слід зазначити, що законодавець також закріпив право медіатора провадити свою діяльність на оплатній чи безоплатній основі відповідно до ст. 11 законопроєкту [5]. Це означає, що в принципі громадські об'єднання медіаторів, що створюються для некомерційних цілей, можуть надавати послуги з проведення медіації на безоплатній основі, але це ініціатива саме громадських об'єднань. На мою думку, повинна існувати також гарантована державою можливість безоплатно отримати послуги медіації у кримінально-правовій сфері конфліктів незахищеним верствам населення.

Вважаю за потрібне також окреслити межі, у яких український законодавець бачить застосування медіації у кримінальному процесі. Через те, що законопроєкт передбачає, що медіація у кримінальному процесі буде проходити у відповідності до угоди про примирення між потерпілим та підозрюваним чи обвинуваченим, межі застосування цієї процедури автоматично переходять і до медіації у кримінальному процесі.

Тобто відповідно до ч. 3 ст. 469 Кримінального процесуального кодексу медіація може застосовуватись до кримінальних проступків, нетяжких злочинів, а також до кримінальних проваджень у формі приватного обвинувачення [6].

Зважаючи на те, що медіація у кримінальному процесі - це все ж таки нововведення, такі обмеження стосовно тяжкості злочинів я вважаю 
абсолютно доречними. Незважаючи на те, що міжнародна практика показала доцільність застосування медіації і до більш тяжких злочинів, нині для українського суспільства важлива поступовість.

Найголовнішим моментом введення такої процедури є не ціль відповідати прогресу і світовій практиці, a можливість покращити власний кримінальний процес та доповнити його тими компонентами, які дадуть змогу кожному учаснику процесу відчути полегшення i, можливо, отримати відповіді на свої питання. Через те, що сам процес медіації передбачає очні сесії за участю потерпілого та правопорушника, напевно, більшість людей переживають саме через можливу ревіктимізацію, тобто повторне травмування жертви. I справді, навіть за наявності професійного медіатора, який спеціалізується на кримінальному процесі, цей ризик залишається. Саме тому я вважаю, що вимоги до медіатора, який спеціалізується на кримінальному процесі, повинні бути більш жорсткими, а також погоджуюсь 3 тим, щоб медіація застосовувалась саме до тих категорій злочинів, які зазначені у Кримінальному процесуальному кодексі, у межах угоди про примирення між потерпілим та підозрюваним чи обвинуваченим.

Проаналізувавши логіку законодавця стосовно запровадження медіації у кримінальний процес, вважаю, що, окрім зазначення того, яким чином 3 процесуальної точки зору має відбуватись процес медіації, повинні також висуватись вимоги до безпеки проведення цього процесу.

Саме цей момент відповідає на питання тих людей, які побоюються ревіктимізації чи, можливо, повторного скоєння злочину. Який би стаж не був у медіатора, скільки б навчань він не пройшов, все одно залишаються ризики того, що на медіації відбудеться якась непередбачувана ситуація. На мій погляд, це можна було б вирішити за допомогою елементарних правил безпеки, таких як тривожна кнопка у медіатора чи наявність охоронця, який стоїть за дверима, чи камери спостереження, за якою спостерігає охоронець, який теж підписує договір про конфіденційність, щоб це не порушувало правила медіації. Усі ці моменти залишаються неврегульованими ні в законопроєкті «Про медіацію», ні в Кримінальному процесуальному кодексі.

Тому, посилаючись на вищенаведене, можна зробити висновок, що запровадження медіації у кримінальний процес на базі угоди про примирення між потерпілим та підозрюваним чи обвинуваченим є доцільним рішенням, яке одразу вирішує більшість питань стосовно процесу медіації. Також, на мою думку, було б недоречно створювати окремий інститут медіації у кримінальному процесі 3 огляду на те, що угоди про примирення між потерпілим та підозрюваним чи обвинуваченим повністю відповідають філософії і суті медіації, ціль якої - примирення та пошук шляхів до примирення. Але беручи до уваги, що медіація у кримінальному процесі має свою специфіку, вона повинна бути додатково врегульована, і просто помістити медіацію у рамки угод про примирення між потерпілим та підозрюваним чи обвинуваченим не досить. Питання підвищення вимог до медіаторів у кримінальному процесі та створення доступу до цієї послуги незахищеним верствам населення при цьому залишаються невизначеними. Питання додаткової безпеки самої процедури медіації також повинне порушуватись у подальшому впровадженні медіації. 


\section{Список використаних джерел}

1. Мельничук Ю.І., Калінін В.В. Порівняльна характеристика впровадження інституту медіації в зарубіжних країнах та Україні. Молодий вчений. № 12.1 (76.1). 2019. C. $42-45$.

2. Закон України від 3 серпня 2006 р. № 69-V «Про ратифікацію Європейської конвенції про здійснення прав дітей». URL: http://rada.gov.ua/.

3. Медіація як процедура врегулювання спорів шляхом досягнення консенсусу. Інститут законодавства Верховної Ради України, Мюнхенський Інститут східноєвропейського права. Київ : Інститут законодавства Верховної Ради України, 2011. 236 с.

4. URL: http://conventions.coe.int/Treaty/Commun/QueVoulezVous.

5. Про медіацію : проєкт Закону України від 19.05.2020 р. реєстр. № 3504 URL: http://search.ligazakon.ua/1 doc2.nsf/link1/JI02134A.html.

6. Кримінальний процесуальний кодекс : Закон України від 13.04.2012. Вiдомості Верховної Ради України. 2013. № 9-10. С. 474. Ст. 88.

Роскошна Н. Г. Медіація у рамках угоди про примирення між потерпілим та підозрюваним чи обвинуваченим

У цій статті аналізується такий альтернативний спосіб вирішення спорів, як медіація, що розглядається у рамках угоди про примирення між потерпілим та підозрюваним чи обвинуваченим. Автор досліджує впровадження медіації у кримінальний процес України і наводить актуальність запровадження цього альтернативного способу вирішення спору у законодавство України. Спираючись на міжнародно-правову практику, а також на сучасний стан української правової системи автор доходить висновку про необхідність такого запровадження. Також у статті аналізується вибраний українськими законодавцями шлях до запровадження цього альтернативного способу вирішення спорів у кримінальний процес на базі наявного законопроєкту «Про медіацію». Разом із тим автор наводить питання, які не регулюються ні законопроєктом, ні наявним Кримінальним процесуальним кодексом України, на які потрібно звернути увагу. У статті аналізуються вимоги до медіатора, які, на думку автора, повинні бути більш жорсткими, вбачаючи специфіку медіації саме у кримінальному процесі, а також порушуються питання про доступ до цієї послуги незахищених верств населення, які неспроможні заплатити кошти медіатору. Особлива увага звертається саме на безпечність процесу медіації, тому що саме від цього залежить сприйняття суспільством такого нововведення. На думку автора, це одне 3 ключових питань, яке треба обговорювати і яке повинне регулюватись на законодавчому рівні. Основне питання, яке порушує автор, - доцільність впровадження медіації у рамках наявної у Кримінальному процесуальному кодексі України процедури, а саме угод про примирення між потерпілим та підозрюваним чи обвинуваченим, аналізується логіка законодавця та доцільність саме такого шляху впровадження. Розглядається філософсько-правовий аспект вбудовування медіації в інститут угод про примирення між потерпілим та підозрюваним чи обвинуваченим, оскільки важливо, щоб медіація не втрачала жодних якостей, елементів і принципів, які їі характеризують. На підставі проаналізованого законодавства та нового законопроєкту «Про медіацію» автор статті робить висновки стосовно порушених у статті питань.

Ключові слова: відновне правосуддя, програми примирення потерпілих і правопорушників, альтернативний спосіб вирішення спорів, кримінально-правовий конфлікт, кримінальний процес.

Roskoshna N. Mediation under the agreement of reconciliation between the victim and the suspect or the accused

This article analyzes such an alternative way of resolving disputes as mediation, which is considered in the framework of a conciliation agreement between the victim and the suspect or accused. The author examines the introduction of mediation in the criminal process of Ukraine and cites the relevance of introducing this alternative method of dispute resolution in the 
legislation of Ukraine. Based on international legal practice, as well as on the current state of the Ukrainian legal system, the author concludes that such an introduction is necessary. Also, the article analyzes the way chosen by Ukrainian legislators to introduce this alternative method of resolving disputes in criminal proceedings on the basis of the current bill "On Mediation", and at the same time, raises issues that are not regulated by the bill or the existing Criminal Procedure Code of Ukraine. The article analyzes the requirements for a mediator, which in the author's opinion should be stricter, seeing the specifics of mediation in criminal proceedings, as well as raises questions about access to this service for vulnerable groups who are unable to pay the mediator. Particular attention is paid to the safety of the mediation process, because it depends on the public perception of such an innovation. According to the author, this is one of the key issues that should be discussed and should be regulated at the legislative level. The main issue raised by the author is the expediency of introducing mediation within the existing procedure in the Criminal Procedure Code of Ukraine, namely: reconciliation agreements between victim and suspect or accused, the logic of the legislator and the expediency of such a way of implementation. The philosophical and legal aspect of embedding mediation in the institution of reconciliation agreements between the victim and the suspect or accused is considered, as it is important that mediation does not lose any qualities, elements and principles that characterize it. Based on the analyzed legislation and the new draft law "On Mediation", the author of the article draws conclusions regarding the issues raised in the article.

Key words: restorative justice, reconciliation programs for victims and offenders, alternative dispute resolution, criminal conflict, criminal procedure. 